ISSN 1991-8631

Original Paper

http://indexmedicus.afro.who.int

\title{
Study of physico-chemical characteristics of the westernmost part of the barrier Lagoon complex, Western Nigeria
}

\author{
A. S. YAKUB*, J. K. IGBO, K. J. BALOGUN, A. O. AGWU, B. O. BELLO \\ and J. APPIA
}

Nigerian Institute for Oceanography and Marine Research, Victoria Island, Lagos, Nigeria.

*Corresponding author, E-mail: demolaniomr@yahoo.com

\begin{abstract}
Some physico-chemical parameters of Badagry Creek and Ologe Lagoon in the Barrier Lagoon Complex of western Nigerian coastal zone were measured on quarterly basis from June 2011 to May 2012. Water samples were collected and analyzed using standard methods at five stations in each of the two water bodies. A brackish condition was observed in Badagry Creek with salinity range of $2.00 \pm 3.8 \%$ o to $3.85 \pm 4.48$ \%o while entirely freshwater condition was recorded in Ologe Lagoon. Surface water temperature, $\mathrm{pH}$, alkalinity, nitrate and phosphate at every station in the two water bodies were within the normal ranges considered suitable for tropical aquatic life. However, high levels of biochemical oxygen demand (BOD) were recorded at a station in Badagry Creek $(8.15 \pm 1.66 \mathrm{mg} / \mathrm{l})$ and two stations in Ologe Lagoon $(16.9 \pm 10.46$ and $9.40 \pm 7.56 \mathrm{mg} / \mathrm{l})$, where untreated municipal wastes are being discharged into the water bodies. These stations also had relatively low dissolved oxygen (DO) levels $(3.30 \pm 0.22,1.08 \pm 0.96$ and $3.68 \pm 3.2 \mathrm{mg} / \mathrm{l}$ respectively). Relatively high levels of lead were also recorded at these stations $(0.50 \pm 0.42,0.85 \pm 0.07$ and $0.35 \pm 0.35 \mathrm{mg} / \mathrm{l}$ respectively). The implications of the physico-chemical conditions on bio-communities as well as the imperativeness of regulating the discharge of untreated wastes into the water bodies for their sustainable management and conservation are discussed.
\end{abstract}

(c) 2013 International Formulae Group. All rights reserved.

Keywords: Physico-chemical parameters, Badagry Creek, Ologe Lagoon, untreated waste discharge, Organic pollution.

\section{INTRODUCTION}

Study of physico-chemical status is very important in assessing ecological conditions of every natural water body. Apart from providing ecological background information, assessment of physico-chemical conditions is also a way by which the health status of natural water bodies can be evaluated
(Yakub, 2004; Yakub and Ugwumba, 2009; Nkwoji et al., 2010).

Barrier-lagoon complex is the westernmost of the four coastal geomorphic divisions in Nigeria. The Barrier-lagoon complex just like other coastal divisions offers immense socio-economic values especially by supporting artisanal sector of capture fisheries and provision of water for domestic and

(C) 2013 International Formulae Group. All rights reserved. DOI : http://dx.doi.org/10.4314/ijbcs.v7i4.30 
industrial uses. Coastal water bodies also provide potentials and opportunities for coastal aquaculture which is very imperative for bridging the gap between demand and supply of fish and allied products in Nigeria.

Little information exists on physicochemical hydrology in the westernmost axis of the barrier-lagoon complex especially in Badagry Creek and Ologe Lagoon. In this study, the physico-chemical hydrology of the Badagry Creek and Ologe Lagoon was investigated. The findings in the study are invaluable for sustainable management and conservation of the fisheries and other resources in the water bodies.

\section{MATERIALS AND METHODS}

\section{Study area}

The study was carried out in Badagry

Creek and Ologe Lagoon within the western axis of the Barrier-Lagoon Complex in Nigeria (Figure 1).

The Badagry Creek is the main body of the barrier lagoon complex that enters Nigeria (Figure 1). It has connections to the sea via Lake Nokoue in Cotonu and Lagos Lagoon and Harbor in Lagos. Ologe Lagoon on the other hand is a backwater into which some rivers and streams in the western part of Nigeria drain, and it in turn empties through some tributaries into the Badagry Creek and Lagos Lagoon (Figure 1).

Five stations were selected in each of Badagry Creek (stations A1 to A5) and Ologe Lagoon (B1 to B5) for sample collections. The sampling stations in Badagry Creek lie between Longitude $2^{0} 52.51^{\prime \prime} \mathrm{E}$ and $3^{0} 06.3^{\prime \prime} \mathrm{E}$ and Latitude $6^{\circ} 24.48$ " and $6^{\circ} 24.78$ "N while those in Ologe Lagoon are between Longitude $3^{0}$ 5.64" $\mathrm{E}$ and $3^{0}$ 6.57' $\mathrm{E}$ and Latitude $6^{0}$ 27.31 "N and $6^{\circ} 29.98$ "N (Figure 1). Littoral mangroves and coconut are the major vegetation of the study area in the Badagry Creek while Ologe Lagoon was characterized mostly by rooted and floating macrophytes as well as dense rainforest especially in areas with low anthropogenic activities

Apart from sand mining and motorized boat operations which are major activities observed in the two water bodies, wastes from a major market in Badagry are discharged into Badagry creek at a location close to station A5. Ologe Lagoon receives municipal effluents through drainage canals at Agbara (station B1) and wastes from an abattoir at Ijanikin (station B2).

\section{Sample collections}

Air and surface water temperatures were measured in situ at every station using mercury-in-glass thermometer. Salinity, conductivity and $\mathrm{pH}$ were measured using a multi-parameter water checker (Horiba U-10) while alkalinity was determined using titration method (APHA, 1995). Dissolved oxygen was determined using iodometric Winkler's method (APHA 1995) while BOD was determined after five days incubation (APHA 1995)

Nitrate, phosphate, sulfate, lead and zinc were measured using colorimetric analysis and spectroscopy with SmartSpectrophotometer by LaMotte. The SmartSpectrophotometer by LaMotte is an American EPA accepted instrument with test procedures that are approved for National Pollutant Discharge Elimination System (NPDES) compliance monitoring programmes (www.lamotte.com). Sample collection and analysis were done in the months of June and September 2011 as well as February and May 2012.

\section{Data analysis}

Data collected during various sampling periods were pooled and analysed statistically using ANOVA Test under Microsoft Excel as prescribed in Ogbeibu (2005). 


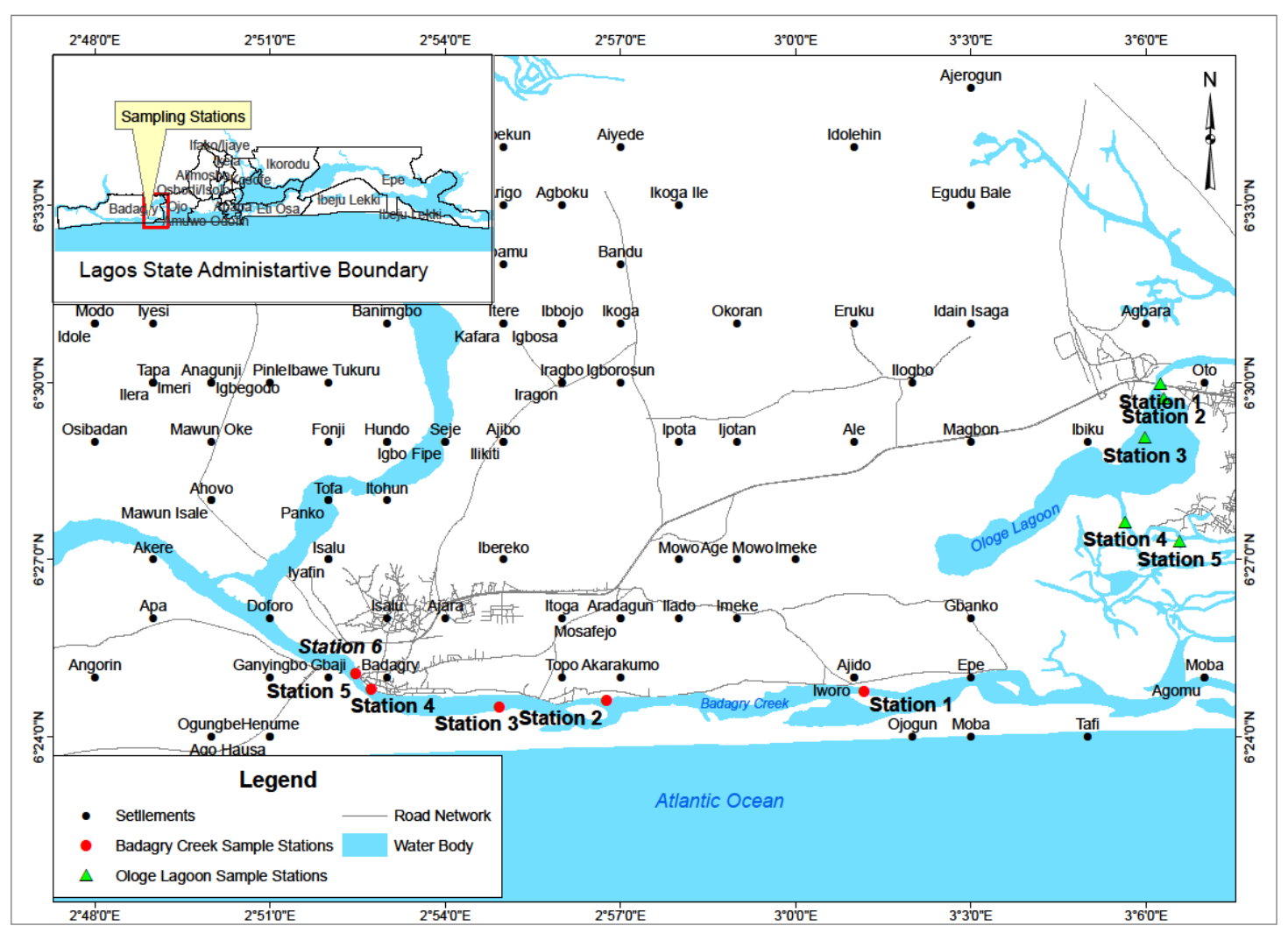

Figure 1: Map showing sampling stations in Badagry Creek and Ologe Lagoon.

\section{RESULTS}

\section{Badagry Creek}

Water temperature values which ranged from $31.1 \pm 1.44{ }^{\circ} \mathrm{C}$ at station $\mathrm{A} 1$ to $31.75 \pm$ $0.5{ }^{\circ} \mathrm{C}$ at station $\mathrm{A} 5$ were not significantly $(p>0.05)$ different. Spatial distributions of the physico-chemical parameters of Badagry Creek are presented in Table 1. Salinity ranged from $2.0 \pm 3.8 \%$ o to $3.85 \pm 4.48 \%$ o with insignificant differences ( $p>0.05$ ) (Table 1). Of all the parameters, only BOD had significant spatial variation $(\mathrm{p}<0.05)$ with a range of $2.21 \pm 2.51 \mathrm{mg} / \mathrm{l}$ at station $\mathrm{A} 2$ to 8.151 $\pm 1.66 \mathrm{mg} / \mathrm{l}$ at station A5. Station A5 also had the highest levels of lead and zinc while the lowest level of lead was recorded at station A1 (Table 1).

\section{Ologe Lagoon}

Air and water temperatures as well as salinity, alkalinity, $\mathrm{pH}$, conductivity, nitrate, phosphate and sulphate and zinc were not significantly different $(p>0.05)$ across the stations. Table 2 presents mean values of the physico-chemical parameters at various stations in Ologe Lagoon. Significant variations $(p<0.05)$ were however recorded in DO, BOD and lead. Station B1 had the lowest mean DO $(1.08 \pm 0.96 \mathrm{mg} / \mathrm{l})$ but the highest mean BOD $(16.90 \pm 10.46 \mathrm{mg} / \mathrm{l})$ and lead $(0.85 \pm 0.07 \mathrm{mg} / \mathrm{l})$ followed by station B2 with mean DO of $3.68 \pm 3.15 \mathrm{mg} / \mathrm{l}$, BOD of $9.4 \pm 7.56 \mathrm{mg} / \mathrm{l}$ and lead of $0.35 \pm 0.35 \mathrm{mg} / \mathrm{l}$ (Table 2). 
Table 1: Spatial distributions of Physico-chemical parameters in Badagry Creek.

\begin{tabular}{|c|c|c|c|c|c|c|}
\hline Parameters & A1 & $\mathbf{A 2}$ & $\mathbf{A 3}$ & A4 & A5 & $\begin{array}{c}\mathbf{P} \\
\text { Value }\end{array}$ \\
\hline A.T $\left({ }^{\circ} \mathrm{C}\right)$ & $29.75 \pm 2.2$ & $29.10 \pm 0.12$ & $28.75 \pm 0.5$ & $28.30 \pm 0.89$ & $28.7 \pm 0.48$ & $>0.05$ \\
\hline W.T $\left({ }^{\circ} \mathrm{C}\right)$ & $31.1 \pm 1.44$ & $31.38 \pm 0.75$ & $31.5 \pm 0.58$ & $31.4 \pm 0.43$ & $31.75 \pm 0.5$ & $>0.05$ \\
\hline Salinity $(\% o)$ & $3.85 \pm 4.48$ & $3.57 \pm 404$ & $2.00 \pm 3.80$ & $3.24 \pm 3.54$ & $3.12 \pm 3.39$ & $>0.05$ \\
\hline $\mathrm{DO}(\mathrm{mg} / \mathrm{l})$ & $5.73 \pm 1.16$ & $5.60 \pm 0.86$ & $5.63 \pm 1.78$ & $5.60 \pm 0.86$ & $3.30 \pm 0.22$ & $>0.05$ \\
\hline Alkalinity $\left(\mathrm{mg} \mathrm{CaCO}_{3} / 1\right.$ & $10.05 \pm 1.6$ & $8.00 \pm 3.65$ & $11.5 \pm 2.52$ & $9.50 \pm 2.52$ & $12.00 \pm 5.89$ & $>0.05$ \\
\hline $\mathrm{pH}$ & $7.78 \pm 0.42$ & $7.67 \pm 0.30$ & $7.80 \pm 0.30$ & $7.62 \pm 0.58$ & $7.69 \pm 0.89$ & $>0.05$ \\
\hline BOD (mg/l) & $4.15 \pm 2.51$ & $2.20 \pm 2.51$ & $2.60 \pm 1.86$ & $3.50 \pm 2.43$ & $8.15 \pm 1.66$ & $<0.05$ \\
\hline Conductivity ( $\mu$ ohms) & $7.63 \pm 6.82$ & $7.44 \pm 6.06$ & $4.87 \pm 6.33$ & $7.23 \pm 5.25$ & $7.13 \pm 5.03$ & $>0.05$ \\
\hline Nitrate $(\mathrm{mg} / \mathrm{l})$ & $0.28 \pm 0.16$ & $0.39 \pm 0.20$ & $0.37 \pm 0.32$ & $0.75 \pm 0.61$ & $0.66 \pm 0.49$ & $>0.05$ \\
\hline Phosphate (mg/l) & $1.15 \pm 1.4$ & $1.54 \pm 2.7$ & $1.34 \pm 1.14$ & $1.15 \pm 1.84$ & $0.66 \pm 0.9$ & $>0.05$ \\
\hline Sulphate (mg/l) & $145 \pm 184.3$ & $122.8 \pm 187.3$ & $136.5 \pm 177.8$ & $111.8 \pm 154.8$ & $127.8 \pm 155.4$ & $>0.05$ \\
\hline Lead (mg/l) & $0.05 \pm 0.07$ & $0.1 \pm 0.14$ & $0.1 \pm 0$ & $0.2 \pm 0.14$ & $0.5 \pm 0.42$ & $>0.05$ \\
\hline Zinc (mg/l) & $0.16 \pm 0.09$ & $0.12 \pm 0.03$ & $0.14 \pm 0.002$ & $0.13 \pm 0.10$ & $0.16 \pm 0.05$ & $>0.05$ \\
\hline
\end{tabular}

A.T: Air Temperature

W.T: Water Temperature

Table 2: Spatial distributions of Physico-chemical parameters in Ologe Lagoon.

\begin{tabular}{lcccccc}
\hline Parameters & B1 & B2 & B3 & B4 & B5 & $\begin{array}{c}\text { P } \\
\text { Value }\end{array}$ \\
\hline A.T $\left({ }^{\circ} \mathrm{C}\right)$ & $28.38 \pm 0.48$ & $27.85 \pm 0.89$ & $28.13 \pm 0.9$ & $29.38 \pm 1.5$ & $29.75 \pm 0.96$ & $>0.05$ \\
W.T $\left({ }^{\circ} \mathrm{C}\right)$ & $30.5 \pm 2.4$ & $31.00 \pm 2.2$ & $31.1 \pm 0.13$ & $30.8 \pm 1.0$ & $31.18 \pm 0.6$ & $>0.05$ \\
Salinity $(\% \circ)$ & 0.00 & $0.03 \pm 0.05$ & $0.05 \pm 0.2$ & $0.05 \pm 0.1$ & 0 & $>0.05$ \\
D.O $(\mathrm{mg} / \mathrm{l})$ & $1.08 \pm 0.96$ & $3.68 \pm 3.2$ & $5.93 \pm 0.90$ & $4.50 \pm 2.72$ & $4.48 \pm 1.75$ & $<0.05$ \\
Alkalinity (mg CaCO $/ \mathrm{l})$ & $9.50 \pm 2.52$ & $10.5 \pm 3.42$ & $9.50 \pm 4.43$ & $10.0 \pm 2.83$ & $8.50 \pm 3.79$ & $>0.05$ \\
pH & $7.39 \pm 0.71$ & $7.80 \pm 0.55$ & $7.90 \pm 0.82$ & $7.67 \pm 0.59$ & $7.66 \pm 0.45$ & $>0.05$ \\
BOD (mg/l) & $16.9 \pm 10.46$ & $9.40 \pm 7.56$ & $6.35 \pm 5.12$ & $5.35 \pm 2.22$ & $5.95 \pm 3.89$ & $<0.05$ \\
Conductivity $(\mu \mathrm{ohms})$ & $0.14 \pm 0.05$ & $0.25 \pm 0.16$ & $0.34 \pm 0.16$ & $0.27 \pm 0.20$ & $0.24 \pm 0.13$ & $>0.05$ \\
Nitrate $(\mathrm{mg} / \mathrm{l})$ & $0.16 \pm 0.17$ & $0.13 \pm 0.09$ & $0.23 \pm 0.34$ & $0.14 \pm 0.20$ & $0.47 \pm 0.78$ & $>0.05$ \\
Phosphate $(\mathrm{mg} / \mathrm{l})$ & $1.17 \pm 1.36$ & $0.72 \pm 0.59$ & $0.38 \pm 0.12$ & $1.10 \pm 1.32$ & $0.01 \pm 1.60$ & $>0.05$ \\
Sulphate $(\mathrm{mg} / \mathrm{l})$ & $22.75 \pm 35.0$ & $24.25 \pm 37.4$ & $25.25 \pm 36.8$ & $31.0 \pm 35.7$ & $36.75 \pm 43.2$ & $>0.05$ \\
Lead $(\mathrm{mg} / \mathrm{l})$ & $0.85 \pm 0.07$ & $0.35 \pm 0.35$ & $0.2 \pm 0.14$ & $0.15 \pm 0.07$ & $0.15 \pm 0.07$ & $<0.05$ \\
Zinc $(\mathrm{mg} / \mathrm{l})$ & $0.02 \pm 0.01$ & $0.12 \pm 0.12$ & $0.06 \pm 0.05$ & $0.12 \pm 0.13$ & $0.05 \pm 0.06$ & $>0.05$ \\
\hline & & & & & & \\
\hline
\end{tabular}




\section{DISCUSSION}

Mean water temperatures recorded in the two water bodies study fall within the normal temperature range stipulated for aquatic life in the tropical region (Horsfall and Spiff, 2001). Salinity and conductivity levels recorded in this study indicate a low brackish condition in Badagry Creek while Ologe Lagoon is an entirely fresh water body.

The $\mathrm{pH}$, nitrate and phosphate levels recorded at every station fall within the normal ranges stipulated as standards for tropical aquatic life (Horsfall and Spiff, 2001) and similar to findings earlier made in relatively unperturbed areas of other Nigerian water bodies (Yakub, 2004; Yakub and Ugwumba, 2009; Nkwoji et al., 2010)..

The relatively low alkalinity which perhaps may be due to low lime content of the catchment areas (Adebisi, 1981) indicates low buffering capacity of the water bodies against pH fluctuations (Yakub et al., 2006). The low buffering capacity indicates the vulnerability of the water bodies to adverse consequences of anthropogenic activities such as acidification that alters the $\mathrm{pH}$. Nevertheless, the buffering capacity could be improved by proper liming of the pond if water is to be sourced from Badagry Creek and Ologe Lagoon for coastal pond culture of aquatic organisms.

The BOD levels recorded at station A5 in Badagry Creek as well as stations B1 and B2 in Ologe Lagoon far exceed the upper limit of $4 \mathrm{mg} / \mathrm{l}$ set by FEPA as standard for normal aquatic life. These high BOD levels indicate high level of oxidizable organic substances in the wastes that are being discharged into the water bodies at these stations. BOD provides a measure of the level of organic pollution as a result of consumption of oxygen in the course of biological process of breaking down of the organic molecules into inorganic forms (Horsfall and Spiff,
2001; Abowei and Sikoki, 2005). The low DO levels recorded at stations A5, B1 and B2 are therefore attributable to the high BOD due to the anthropogenic organic load inputs at the stations.

Previous findings of high BOD and low DO levels as a result of elevated level organic-rich wastes input into aquatic environments in Nigeria include those of Yakub (2004, 2010), Arimoro et al. (2007), Edokpayi and Edokpayi (2007), Woke and Wokoma (2007), Yakub and Ugwumba (2009), Lawal-Are et al. (2010), Nkwoji et al. (2010). According to the authors, deoxygenation as a result of BOD imposition can lead to elevation of levels of toxic substances (such as ammonia, nitrite, hydrogen sulfide and methane) which causes reduced fitness or asphyxiation (when severe) for aquatic organisms.

The mean values recorded for lead and zinc in the two water bodies were higher than $0.03 \mu \mathrm{g} / \mathrm{l}$ and $2.5 \mu \mathrm{g} / \mathrm{l}$ reported as the coastal water background levels for the two heavy metals respectively (Ajao et al., 1996). The spatial distributions which showed significantly higher levels of lead also at stations A5, B1 and B2 than other stations indicate that anthropogenic inputs were most likely to account for high levels of lead in these water bodies.

The presence of lead and zinc at high levels could be of critical ecological significance to the water bodies. Heavy metals generally are pollutants of high priority due to the relatively low toxicity threshold of many species to a vast range of aquatic organisms. This can lead to reduction in biological populations and loss of biodiversity (Oyewo and Don-Pedro, 2003; Otitoloju et al., 2007). Furthermore, due to their non-degradable nature, the heavy metals can bioaccumulate to very high concentrations at higher trophic levels chains especially in edible aquatic 
species (such as finfish and shell fish), thus posing serious health hazards to man (DonPedro et al., 2004).

\section{Conclusion}

The findings in this study show a low brackish and fresh water condition in Badagry Creek and Ologe lagoon respectively. The surface water temperature, $\mathrm{pH}$, nitrate, phosphate and sulfate of the water bodies are within desirable levels. The water bodies however have relatively low alkalinity which indicates low buffering capacity against $\mathrm{pH}$ fluctuations.

The results also show the adverse effects of discharges of untreated wastes on the water bodies as manifested by low dissolved oxygen as well as high levels of biochemical oxygen demand, zinc and lead at the stations where these activities take place. In order to ensure sustainable management of the water bodies and socio-economically important fisheries resources therein, it is imperative to control the discharge of untreated wastes into the water bodies by appropriate regulatory authorities.

Furthermore, for conservation of the biodiversity, further studies especially on various biological communities of the water bodies are recommended. It is also imperative to ensure regular monitoring of the levels of toxic contaminants such as the heavy metals especially in edible species of the water bodies to ensure consumer safety.

\section{REFERENCES}

Abowei JF, Sikoki FD. 2005. Water Pollution; Management and Control. Double Trust Publishers: Port Harcourt, Nigeria; 254 p.

Adebisi AA. 1981. The physico-chemical hydrology of a tropical seasonal River Upper Ogun River. Hydrobiologia, 79: $157-165$.
Ajao EA, Oyewo EO, Uyimadu JP. 1996. Review of the pollution of coastal waters in Nigeria. NIOMR, 107: $6-7$.

APHA/AWWA/WPCF. 1995. Standard Methods for the Examination of Water and Waste Water (16 ${ }^{\text {th }}$ edn). APHA/AWWA/WPCF: Washington. 1041-1195.

Arimoro FO, Ikomi RB, Osalor EC. 2007. The impact of sawmill wood wastes on water quality and fish communities of Benin River, Niger Delta area, Nigeria. International Journal of Science \& Tech., 2(1): 1-12.

Don-Pedro KN, Oyewo EO, Otitoloju AA. 2004. Trend of Heavy Metal Concentrations in Lagos Lagoon Ecosystem, Nigeria. West African Journal of Applied Ecology, 5: 103-113.

Edokpayi CI, Nkwoji JA. 2007. Annual changes in the physico-chemical and macro-benthic invertebrate characteristics of the Lagos Lagoon sewage dump site at Iddo, southern Nigeria. Ecol. Env. Cons., 13(1): 13-18.

Horsfall M, Spiff AI. 2001. Environmental Pollution with Biological, Chemical and Physical Emphasis. Metro print Ltd.: Port Harcourt, Nigeria; 368.

Lawal-Are AO, Onyema IC, Akande TR. 2010. The water chemistry, crustacean zooplaknton and some associated faunal species of a tropical tidal creek in Lagos,Nigeria. Journal of American Science, 6(1): 81-90.

Nkwoji JA, Yakub A, Ajani GE, Balogun KJ, Renner KO, Igbo JK, Ariyo AA, Bello BO. 2010. Seasonal variations in the water chemistry and benthic macroinvertebrates of a south western lagoon, lagos. Nigeria. Journal of American Science, 6(3): 85-92.

Ogbeibu AE. 2005. Biostatistics: A Practical Approach to Research and Data 
Handling. Mindex Publishing Company Limited.: Nigeria; 264.

Otitoloju AA, Don-Pedro KN, Oyewo EO. 2007. Assessment of potential ecological distruption based on heavy metal toxicity, accumulation and distribution in media of the Lagos Lagoon. Afr. J. Ecol., 45: 454463.

Oyewo EO, Don-Pedro KN. 2003. Acute Toxicity and Bioaccumulation of mercury and copper in Calibarinus Africanus and Tympanotonus fuscatus. Journal of Aquatic Science, 18(2): 75-84.

Woke GN, Wokoma IPA. 2007. Influence of abattoir wastes on the physio-chemical parameters of the New Calabar River at Choba, Port Harcourt, Nigeria. African Journal of Applied Zoology and Environmental Biology, 9: 5-7

Yakub AS. 2004. Assessment of water quality and plankton of effluents receiving Awba Stream and Reservoir, Ibadan, Nigeria. African Journal of Applied
Zoology and Environmental Biology, 6: 107-110.

Yakub AS. 2010. Ecological impacts of Abattoir effluent, using composition and distribution of Insect fauna in Lower Ogun River, Southwest Nigeria. Journal of Aquatic Sciences, 25(1): 98-104.

Yakub AS, Opara JY, Anyanwu PE. 2006. Diurnal tidal regime and water quality of the New Calabar River and fresh water tidal ponds at African Regional Aquculture Center, Aluu, Port Harcourt. In Proceedings of the $20^{\text {th }}$ Annual Conference of the Fisheries Society of Nigeria, Port Harcourt $14^{\text {th }}-18^{\text {th }}$ Nov. 2005, Ansa EJ, Anyanwu PE, Ayonadu BW, Erondu ES, Deekae SN (eds). 78-84. Yakub AS, Ugwumba AAA. 2009. Effects of Abattoir effluents on some physicochemical parameters and freshwater prawns (Macrobrachium) of Lower Ogun River, Western Nigeria. Nigerian Journal of Fisheries, 6(2):93-101. 